\title{
ASSOCIATIONS BETWEEN BLOOD AND CEREBROSPINAL FLUID FLOW IMPAIRMENTS ASSESSED WITH PHASE-CONTRAST MRI AND BRAIN DAMAGE IN PATIENTS WITH AGE-RELATED CEREBRAL SMALL VESSEL DISEASE
}

Kremneva El ${ }^{1}$, Akhmetzyanov BM², Dobrynina LA' ${ }^{1}$ Krotenkova MV1

${ }^{1}$ Research Center of Neurology, Moscow, Russia

PET-Technology LLC, Ufa, Russia

Hemodynamic parameters of blood and cerebrospinal fluid (CSF) flow can be measured in vivo using phase-contrast MRI (PC-MRI). This opens new horizons for studying the mechanisms implicated in the development and progression of age-related cerebral small vessel disease (SVD). In this paper, we analyze associations between cerebral arterial, venous and CSF flow impairments and SVD features visible on MRI. The study was carried out in 96 patients with SVD (aged $60.91 \pm 6.57$ years) and 23 healthy volunteers ( $59.13 \pm 6.56$ years). The protocol of the MRI examination included routine MRI sequences (T2, FLAIR, T1, SWI, and DWI) applied to assess the severity of brain damage according to STRIVE advisory standards and PC-MRI used to quantify blood flow in the major arteries and veins of the neck, the straight and upper sagittal sinuses, and CSF flow at the aqueduct level. We analyzed the associations between linear and volumetric parameters of blood/CSF flow and the degree of brain matter damage using the Fazekas scale. We observed a reduction in tABF, stVBF, sSsVBF, aqLF, Saq, and ICC values and a rise in $\mathrm{Pi}$ associated with $\mathrm{WMH}$ progression, as well as a gradual decline in $\mathrm{ABBF}$ and an increase in $\mathrm{Pi}$, Saq and ICC associated with a growing number of lacunes $(p<0.05)$. Patients with early $(<5)$ MB had lower sSsVBF and stVBF rates in comparison with patients without MB; aqLF, Saq, and ICC values were elevated in patients with 5 to $10 \mathrm{MB}$, as compared to patients without MB or early $(<5) \mathrm{MB}$. The established associations between MRI findings in patients with SVD and blood/CSF flow impairments suggest the important role of mechanisms implicated in the disruption of Monro-Kellie intracranial homeostasis in promoting SVD.

Keywords: phase-contrast MRI, age-related small vessel disease, blood flow, CSF flow

Funding: this work was part of the state assignment for Research Center of Neurology.

Author contribution: Kremneva El — methodology of the study, data analysis and interpretation, manuscript preparation; Akhmetzyanov BM — data acquisition, statistical processing and interpretation; Dobrynina LA - conception and methodology of the study, data interpretation, clinical data analysis and acquisition; Krotenkova MV — study supervision and methodology, data interpretation.

Compliance with ethical standards: the study was approved by the Ethics Committee of the Research Center of Neurology (Protocol № 2-3/16 dated January 27. 2016). Informed consent was obtained from all study participants.

$\triangle$ Correspondence should be addressed: Elena I. Kremneva

Volokolamskoe shosse 80, Moscow, 125367; kremneva@neurology.ru

Received: 28.07.2019 Accepted: 12.08.2019 Published online: 25.08.2019

DOI: $10.24075 /$ brsmu.2019.054

\section{ВЛИЯНИЕ НАРУШЕНИЙ КРОВОТОКА И ЛИКВОРОТОКА ПО ДАННЫМ ФАЗОВО-КОНТРАСТНОЙ МРТ НА СОСТОЯНИЕ ГОЛОВНОГО МОЗГА ПРИ ВОЗРАСТ-ЗАВИСИМОЙ ЦЕРЕБРАЛЬНОЙ МИКРОАНГИОПАТИИ}

Е. И. Кремнева ${ }^{凶}$, Б. М. Ахметзянов², Л. А. Добрынинаㄹ, М. В. Кротенкова

${ }^{1}$ Научный центр неврологии, Москва, Россия

2 ООО «ПЭТ-Технолоджи», Уфа, Россия

Метод фазово-контрастной МРТ (ФК-МРТ) головного мозга позволяет in vivo оценить показатели кровотока и ликворотока, что открывает новые возможности в исследовании механизмов развития и прогрессирования возраст-зависимой церебральной микроангиопатии (ЦМА). Целью работы было провести анализ значимости нарушений церебрального артериального, венозного кровотока и ликворотока в формировании МРТ-признаков

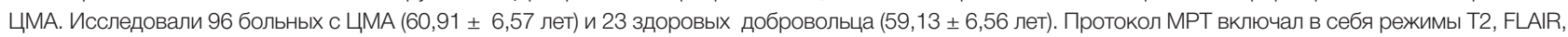
T1, SWI, ДВИ для оценки поражения головного мозга согласно стандартам STRIVE, а также ФК-MPT с оценкой кровотока в магистральных артериях и венах шеи, в прямом и верхнем сагиттальном синусах, ликворотока на уровне водопровода мозга. Проводили корреляцию линейных и объемных показателей кровотока и ликворотока с поражением вещества мозга в зависимости от степени тяжести изменений (шкала Фазекас). Отмечно снижение tABF, stVBF, sssVBF, aqLF, Saq, ICC и повышение Pi по мере прогрессирования ГИБВ, постепенное снижение tABF и повышение Pi, Saq и ICC по мере увеличения числа лакун ( $p<0,05)$. Значения sssVBF и stVBF также достоверно снижались в группе ранних (<5) МКР по сравнению с больными без МКР, a aqLF, Saq, ICC увеличивались в группе больных с 5-10 MKP по сравнению с больными без МКР и ранними (<5) МКР. Установление связи изменений в артериальном, венозном кровотоке и ликворотоке с МРТ-проявлениями у больных ЦМА позволяет предполагать патогенетическую значимость в развитии ЦМА-механизмов, связанных с нарушением гомеостаза Монро-Келли.

Ключевые слова: фазово-контрастная МРТ, возраст-зависимая церебральная микроангиопатия, мозговой кровоток, ликвороток

Финансирование: работа выполнена в рамках государственного задания ФГБНУ НЦН.

Информация о вкладе авторов: Е. И. Кремнева - методика исследования, анализ и интерпретация данных, написание и оформление статьи; Б. М. Ахметзянов - сбор данных; обработка данных и их интерпретация; статистический анализ; Л. А. Добрынина - общая идея и методология исследования, интерпретация данных, сбор и анализ клинической части данных; М. В. Кротенкова - курирование исследования, методология исследования, интерпретация данных.

Соблюдение этических стандартов: исследование одобрено локальным этическим комитетом ФГБНУ Научный центр неврологии (протокол № 2-3/16 от 27 января 2016 г.). Все участники подписали добровольное информированное согласие на участие в исследовании.

$\triangle$ Для корреспонденции: Елена Игоревна Кремнева

Волоколамское шоссе, д. 80, г. Москва, 125367; kremneva@neurology.ru

Статья получена: 28.07.2019 Статья принята к печати: 12.08.2019 Опубликована онлайн: 25.08.2019

DOI: 10.24075/vrgmu.2019.054 
MR neuroimaging has enabled visualization of the tiniest anatomical structures of the brain and provided new insights into its functions, metabolism, blood supply and cerebrospinal fluid (CSF) circulation. Phase contrast MRI (PC-MRI) is a method of functional MR neuroimaging that yields information about arterial, venous and CSF flows. In conventional PC-MRI, two data sets are acquired and subtracted from each other following the application of bipolar gradients with the same magnitude but opposite directions. The net phase gain will be 0 for stationary spins. However, moving spins will undergo a non-zero phase shift proportional to their velocity. This happens in flowing media, where traveling protons experience a stronger or weaker magnetic field following the application of the second gradient, as compared to the first. Since the amount of phase shift depends on the velocity of protons, PC-MRI can be used to measure hemodynamic parameters of the flow, including velocity [1]. When synchronized with the cardiac cycle, the pulse sequence generates a series of images containing flow velocity data that represent a particular cardiac cycle phase. Thus, a single scan can yield both phase and magnitude images, facilitating flow quantification and brain anatomy visualization.

PC-MRI is mainly used to quantify cerebral fluid flow and assess the efficacy of surgical treatment in patients with hydrocephalus [2]. PC-MRI is a rapid, noninvasive and objective technique for measuring the amount and velocity of arterial, venous and CSF flows and their temporal relationship to cardiac cycle phases; it also provides valuable information about arteries, veins, sinuses and perivascular spaces that determine cerebral compliance [3]. This makes PC-MRI an optimal tool for studying central nervous system disorders arising from the dysfunction of the mentioned intracranial components, including cerebral microangiopathy, also known as small vessel disease (SVD). SVE is essentially a combination of neuroimaging features, morphological and clinical symptoms associated with damage to small arteries, arterioles, capillaries and venules [4]. In Russia SVD is considered to be part of a broader concept referred to as dyscirculatory encephalopathy (DE) [5]. The social impact of SVD should not be underestimated: it accounts for at least $20 \%$ of all strokes and $45 \%$ of dementia cases worldwide [6]. Although the leading risk factors for SVD are hypertension and age [4], the disease is often diagnosed in non-hypertensive elderly patients; in many cases, its etiology is uncertain [7]. This has inspired research into the pathophysiology of SVD and the role of other risk factors [6], including early endothelial dysfunction accompanied by increased permeability of the blood brain barrier (BBB), vasogenic cerebral edema, and white matter damage that impair venous blood flow and affect CSF circulation [8]. Studies elucidating the role of blood or CSF flow impairments in brain damage in patients with SVD are scarce. However, once their role is clarified, the new knowledge can pave the way to novel therapeutic approaches for patients with SVD. Since PC-MRI is a perfect tool for this task, we decided to exploit it in our study. Below, we attempt to investigate the associations between cerebral arterial, venous and CSF flow impairments and SVD features visible on MRI.

\section{METHODS}

The main group consisted of 96 patients with SVD (31 men and 65 women aged $60.91 \pm 6.57$ years) referred to the Research Center of Neurology. The following inclusion criteria were applied: complaints of cognitive decline; MRI findings suggestive of SVD (according to STRIVE neuroimaging guidelines, those are recent small subcortical infarcts, lacunes, white matter hyperintensities $(\mathrm{WMH})$, dilated perivascular spaces (PVS), cerebral microbleeds (MB), and brain atrophy) [9]. Patients with dementia that prevented the examination, stroke or brain damage caused by reasons other than SVD, aphasia, contraindications for $\mathrm{MRI}$, severe pathology, atherosclerosis of major arteries of the head and neck (50\% stenosis) were excluded from the study. The control group comprised 23 healthy volunteers ( 8 men and 15 women aged $59.13 \pm 6.56$ years) with no clinical symptoms and MRI findings suggesting vascular or degenerative brain disease. All patients and all controls underwent a standard neurological examination and did standard neuropsychological tests; their ability to function independently in daily life was also assessed. All participants underwent an MRI scan.

Brain scans were performed using a 3.0 T Magnetom Verio scanner (Siemens AG; Erlangen, Germany) with a 12-channel head coil. Routine MR sequences were used to investigate imaging features of the disease; PC-MRI was carried out to quantify blood and CSF flows.

The protocol for routine $\mathrm{MRI}$ included the following sequences: T2-spin-echo, 3D T1mpr, FLAIR, DWI, and SWI. The acquired images were analyzed in RadiAnt DICOM Viewer, version 3.0.2 (Medixant; Poznań, Poland) in compliance with STRIVE neuroimaging standards. Diffusion-weighted imaging revealed the absence of acute or subacute lacunar infarcts; therefore, we will not discuss them in this work. Fig. 1 shows the basic MR sequences applied in the study and the corresponding findings, including the location and extent of the lesion. The patients were distributed into a few groups based on the total severity of white matter lesions, which was assessed using the Fazekas scale: F1 represented single punctate lesions; F2, beginning confluency of lesions; F3, confluent lesions [12, 13].

Cerebral circulation and CSF flow were assessed with PCMRI synchronized with a peripheral pulse sensor. The frame rate was 32 frames per cardiac cycle. The following scan parameters were applied: TR $=28.7 \mathrm{~ms}$, TE $=8 \mathrm{~ms}$, section thickness $=5.0 \mathrm{~mm}$, field of view $=101 \times 135 \mathrm{~mm}$, matrix $=$ $256 \times 192$ pixels; Venc (velocity encoding value) was $5-20 \mathrm{~cm} / \mathrm{s}$ for CSF flow and $60-80 \mathrm{~cm} / \mathrm{s}$ for blood flow. The slice plane was orientated strictly perpendicular to the direction of blood flow in the internal carotid (ICA) and vertebral (VA) arteries at the C2/C3 level, to the direction of CSF flow at the cerebral aqueduct level and was also perpendicular to blood flow in the straight and superior sagittal sinuses (Fig. 2). The images were processed in Bio Flow Image, Flow Analysis Software, Version 04.12.16 (France). We calculated the amount of blood flow in $\mathrm{ICA}$ and VA, the rates of total arterial blood flow (tABF, $\mathrm{ml} / \mathrm{min}$ ), superior sagittal sinus venous blood flow (sssVBF, $\mathrm{ml} / \mathrm{min}$ ), straight sinus venous blood flow (stVBF, $\mathrm{ml} / \mathrm{min}$ ), aqueduct CSF flow (aqLF, $\mathrm{mm}^{3} / \mathrm{s}$ ) and the area occupied by the cerebral aqueduct (Saq, $\mathrm{mm}^{2}$ ).

Resistance and elasticity (stiffness) of the arterial wall were measured using the pulsatility index $(\mathrm{Pi})$ calculated by the formula: $\mathrm{Pi}=\left(\mathrm{V}_{\max }-\mathrm{V}_{\text {min }}\right) \mathrm{N}_{\text {mean }}$, where $\mathrm{V}_{\text {mean }}$ is the mean blood flow velocity during one cardiac cycle, $V_{\max }$ and $V_{\text {min }}$ are peak and minimal values of blood flow velocity, respectively; the index of intracranial compliance (ICC) = the amount of CSF flow $(\mathrm{mm} / \mathrm{s})$ at the cerebral aqueduct level divided by the amount of blood flowing through an artery $\left(\mathrm{mm}^{3} / \mathrm{s}\right)$; the latter is an area under the arterial flow curve that lies above the mean value of blood flow during the cardiac cycle. Elevated ICC means a deterioration in the ability of the intracranial system, which includes brain tissue, CSF and blood flowing in the vessels, to adapt to an increased volume of any of its components or a 
Recent lacunar infarcts
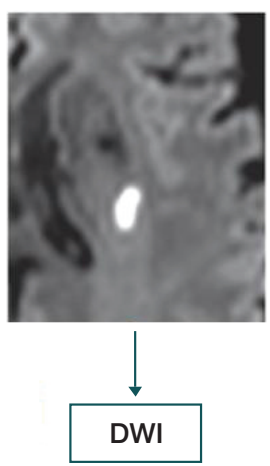

$\downarrow$

No
WMH
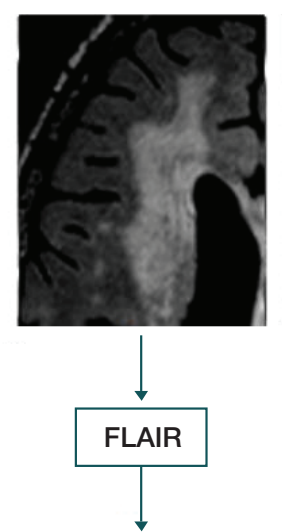

PWM

$0=$ no

$1=$ «caps"

$2=$ «halo"

$3=$ confluent lesion extending to DWM

DWM

DWM

$1=$ single lesions

$2=$ beginning confluency of lesions

$3=$ large confluent lesions

JCWM

$0=$ no

$1=<5$

$2=5-10$

$3=>10 /$ confluent
Lacunes
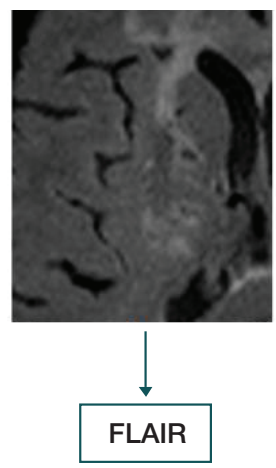

$\downarrow$

$0=$ no

$1=<5$
$=<5$

$2=5-10$

$3=>10 /$ confluent
Perivascular spaces
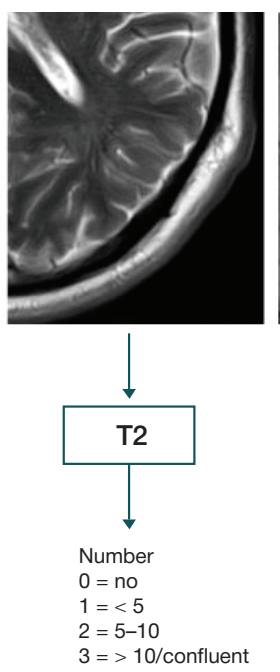

Size

0

$1 \mathrm{~mm}$

$2 \mathrm{~mm}$

$3 \mathrm{~mm}$

Single $4 \mathrm{~mm} /$ >
Microbleeds
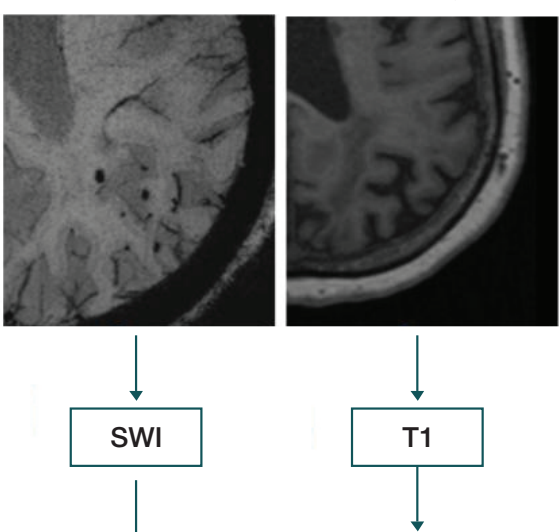

GCA criteria, VBC $_{1-4}$

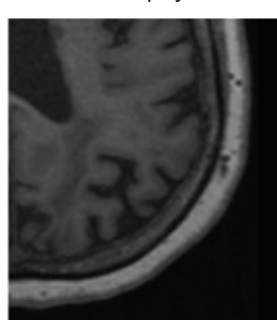

$1=<5$

$2=5-10$

$3=>10 /$ confluent

Fig. 1. An algorithm used to assess MRI features of SVD. PWM — periventricular white matter; DWM — deep white matter; JCWM — juxtacortical white matter [10]; PS — perivascular space; VBC — ventricle to brain coefficient; GCA — global cortical atrophy [11]

lesion, such as a hematoma or a tumor, without inducing a rise in cerebral pressure.

The acquired data were postprocessed in IBM SPSS Statistics 23.0 (IBM Company; USA). The effect of independent quantitative variables on dependent qualitative variables was assessed by one-way ANOVA followed by pairwise comparison and the least significant difference (LSD) test.

\section{RESULTS}

Basic characteristics of MRI features for SVD are provided in Table. PVP > 10 were observed in the semioval centers of 94 (97.9\%) patients and in the subcortical structures of all patients; therefore, we analyzed the degree of their expansion only.

\section{Associations between cerebral arterial blood flow parameters and MRI features of SVD}

The measured hemodynamic parameters of arterial blood flow differed significantly $(p<0.05)$ between the patients with different degrees of severity of $\mathrm{WMH}$, lacunar cavities, PVS dilation, and atrophy in the parietal, temporal and occipital cortex. No associations were established between the severity of $\mathrm{MB}$ or atrophy in other cortical regions and the values of tABF and $\mathrm{Pi}$. The LSD test revealed that the patients with a Fazekas score of 3 had a significantly lower tABF rate and a higher $\mathrm{Pi}$ than the controls or the patients with a Fazekas score of 1 and 2. A gradual decline in tABF and elevated Pi were observed in almost all patients with lacunes, as compared to the patients who did not have lacunar cavities (Fig. 3).

\section{Associations between cerebral venous blood flow parameters and MRI features of SVD}

One-way ANOVA revealed that the hemodynamic parameters of cerebral venous flow in the upper sagittal and straight sinuses (stVBF, sssVBF) differed significantly between the controls and the patients with varying severity of WMH. Further post hoc comparison of the mean values aided by the LSD test revealed a statistically significant decline in stVBF and sssVBF rates in the patients with Fazekas 3, as compared with the controls; in such patients, the stVBF value was also lower than in the patients with a Fazekas score of 2 (Fig. 4).

Using the same statistical tools, we found significant differences in the hemodynamic parameters of cerebral venous flow between the controls and the patients with varying numbers of white matter and subcortical lacunes. A statistically significant decline in stVBF and SssVBF values was observed in the patients with 5 to 10 and > 10 white matter lacunes in comparison with the patients without lacunes. Low stVBF and SSSVBF rates were seen in the patients with 5-10 and $>10$ lacunes and in the patients with $>10$ and $<5$ lacunes in the subcortical ganglia, respectively, in comparison with the patients who did not have lacunar cavities (Fig. 4).

The measured hemodynamic parameters of cerebral venous blood flow differed significantly between the controls and the patients with juxtacortical MB in different brain regions. The post hoc analysis aided by the LSD test revealed a statistically significant correlation between lower sssVBF/stVBF rates and early $\mathrm{MB}(<5)$ in the juxtacortical white matter of the parietal lobe in comparison with patients without MB. We also observed a decline in SSSVBF values in the patients with early $\mathrm{MB}(<5)$ in the deep white matter of the posterior frontal lobe in comparison with the patients without MB.

One-way ANOVA revealed statistically significant differences in SSSVBF rates between the controls and the patients with dilated PVS and an association between stVBF/SSsVBF rates and atrophy of the parietal and temporal lobes.

Associations between blood flow parameters, intracranial compliance and MRI features of SVD

The values of aqLF, Saq and the ICC index differed significantly between the controls and the patients with $\mathrm{WMH}$. The patients 
A

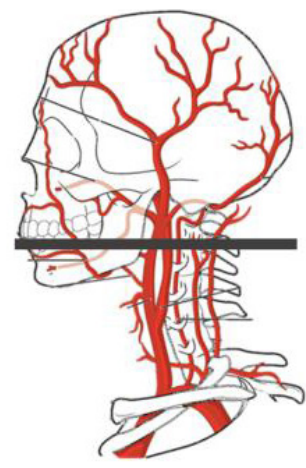

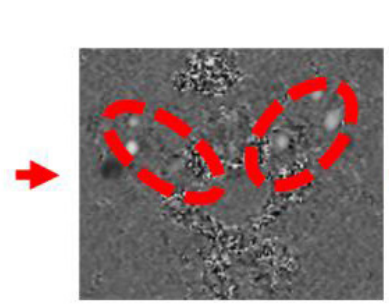

Venc $=80 \mathrm{~cm} / \mathrm{s}$

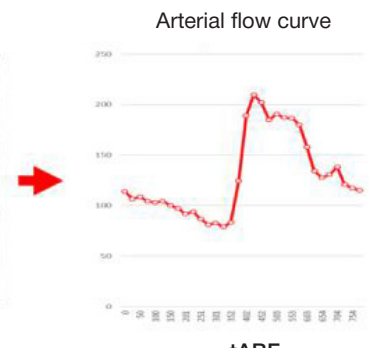

tABF

B
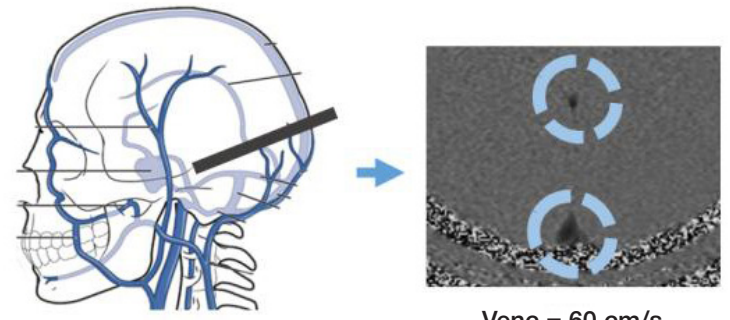

Venc $=60 \mathrm{~cm} / \mathrm{s}$

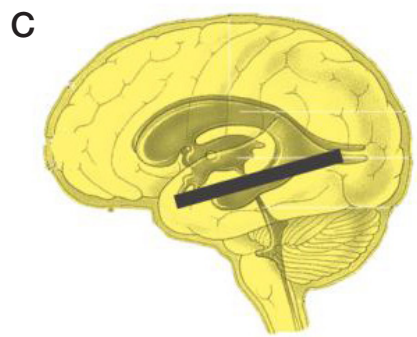

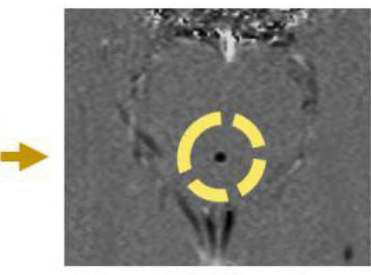

Venc $=10-20 \mathrm{~cm} / \mathrm{s}$

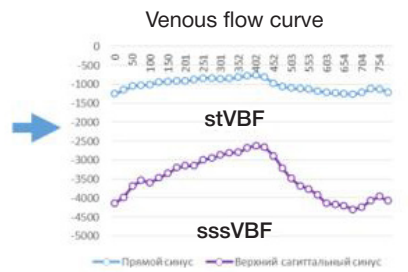

Curve for CSF flow at the aqueduct level

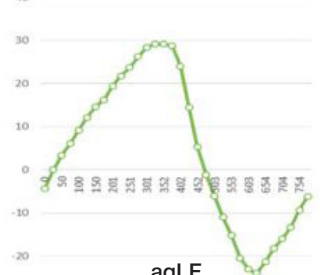

Fig. 2. A schematic representation of the PC-MRI procedure. A. Blood flow in the internal carotid and vertebral arteries. B. Blood flow in the straight and sagittal sinuses. C. CSF flow at the cerebral aqueduct level

with Fazekas 3 had lower aqLF, Saq and ICC than the controls or patients with other Fazekas scores. Increased Saq and elevated ICC were observed in the patients with over 10 white matter lacunes, as compared to the patients who did not have lacunar cavities (Fig. 5). aqLF, Saq, and ICC were increased in the patients with 5 to $10 \mathrm{MB}$ in the juxtacortical white matter of the parietal and temporal lobes in comparison with the patients with a smaller number of $\mathrm{MB}(<5)$ or their total absence.

\section{DISCUSSION}

In this study, we attempted to investigate the associations between vascular and CSF flow changes measured with PC-MRI and SVD features visible on MRI. The analysis of the generated images was guided by STRIVE neuroimaging standards [9]. Previous research works studied the associations between cerebral vascular changes and leukoaraiosis $(\mathrm{WMH})$ or lacunes [14]. Numerous combinations of MRI features seen

Table. MRI findings in patients with SVD. WMH — white matter hyperintensities; MB — cerebral microbleeds; PVS — perivascular spaces; WM — white matter

\begin{tabular}{|c|c|}
\hline Parameter & $n(\%)$ \\
\hline $\begin{array}{l}\text { WMH on the Fazekas scale: } \\
\text { Fazekas } 1 \text { / Fazekas } 2 \text { / Fazekas } 3\end{array}$ & $26(27.1 \%) / 31$ (32.3\%) / 39 (40.6\%) \\
\hline $\begin{array}{l}\text { Lacunes (number of) } \\
\text { in WM of brain hemispheres: } \\
\text { no } /<5 / 5-10 />10 \\
\text { in subcortical structures: } \\
\text { no } /<5 / 5-10 />10\end{array}$ & $\begin{array}{l}42(43.8 \%) / 16(16.7 \%) / 9(9.4 \%) / 17(17.7 \%) \\
32(33.3 \%) / 11(11.5 \%) / 9(9.4 \%) / 12(12.5 \%)\end{array}$ \\
\hline $\begin{array}{l}\text { MB (number of) } \\
\text { in WM of brain hemispheres: } \\
\text { no } /<5 / 5-10 />10 \\
\text { in subcortical structures: } \\
\text { no } /<5 / 5-10 />10\end{array}$ & $\begin{array}{l}28(29.2 \%) / 12(12.5 \%) / 5(5.2 \%) / 11(11.5 \%) \\
28(29.2 \%) / 13(13.5 \%) / 4(4.2 \%) / 11(11.5 \%)\end{array}$ \\
\hline $\begin{array}{l}\text { Brain atrophy: } \\
\text { no / mild / moderate / severe }\end{array}$ & 57 (59.4\%) / 51 (53.1\%) / 6 (6.3\%) / 0 (0\%) \\
\hline $\begin{array}{l}\text { PVS } \\
\text { in semioval centers: } \\
1-2 \mathrm{~mm} / 3 \mathrm{~mm} / 4 \mathrm{~mm} \\
\text { in subcortical structures: } \\
1-2 \mathrm{~mm} / 3 \mathrm{~mm} / 4 \mathrm{~mm}\end{array}$ & $\begin{array}{c}90(93.8 \%) / 4(4.2 \%) / 2(2 \%) \\
68(70.8 \%) / 21(21.9 \%) / 7(7.3 \%)\end{array}$ \\
\hline
\end{tabular}


A

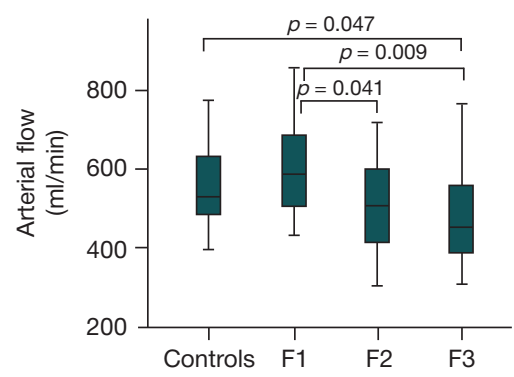

D

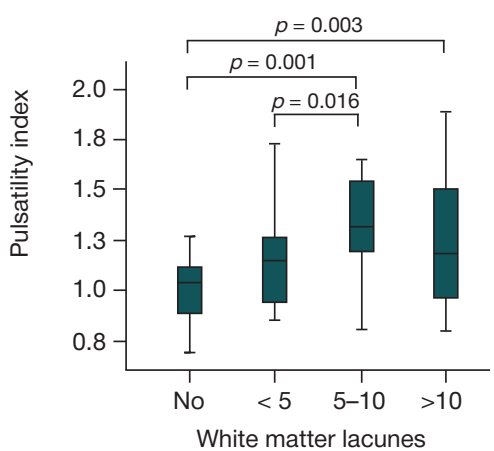

B

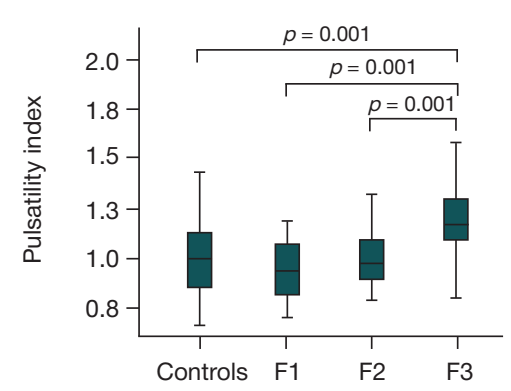

E

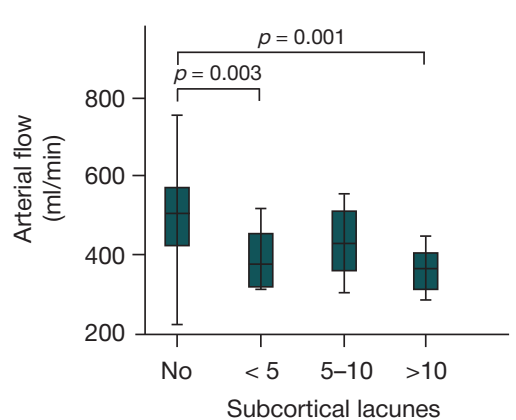

C
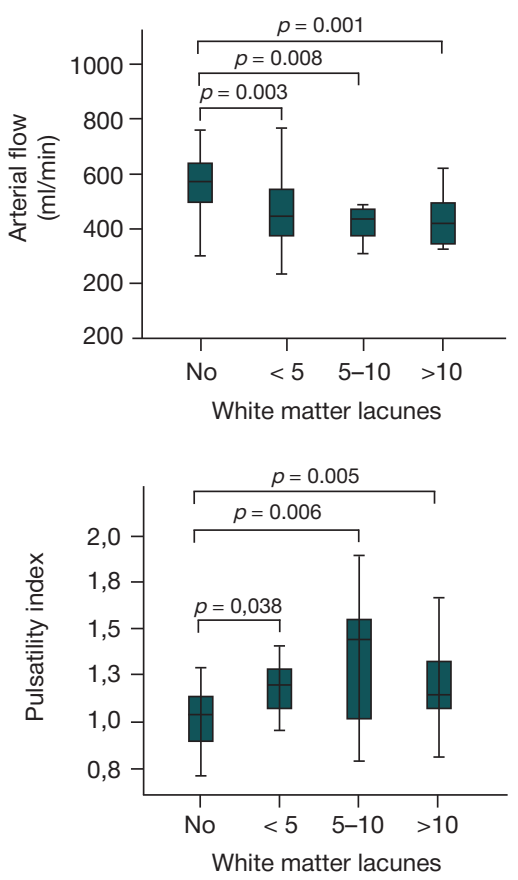

Fig. 3. Comparison of the tABF rate and Pi between the patients with WMH assessed using the Fazekas scale and the controls ( $\mathbf{A}$ and $\mathbf{B}$, respectively), between the groups of patients with different number of lacunes and without lacunes in the white matter (C, D) and subcortical structures (E, F)

in patients with age-related SVD coupled with the absence of a clear association between the severity of $\mathrm{WMH}$, as well as other MRI findings, and the severity of clinical manifestations of the disease led us to hypothesize that neuroimaging features of SVD could be determined by a combination of abnormalities in the intracranial system homeostasis described by the MonroKellie doctrine, with one of such abnormalities prevailing.

Our study discovered that a gradual change in the hemodynamic parameters of arterial, venous and CSF flow was accompanied by $\mathrm{WMH}$ exacerbation measured on the Fazekas scale. However, we were able to establish a statistically significant association only between Fazekas 3 (as compared to the control group) and the measured hemodynamic parameters, including low tABF, elevated $\mathrm{Pi}$, low stVBF/sssVBF, increased aqLF, Saq and ICC, and Fazekas 3. The cooccurrence of blood and CSF flow impairments in patients with severe $\mathrm{WMH}$, which is the main $\mathrm{MRI}$ feature for SVD, suggests the complexity of mechanisms underlying the disruption of intracranial homeostasis. Our findings are consistent with the results of studies of SVD morphology that reported vascular changes associated with atherosclerosisinduced ischemia and venous collagenosis leading to vascular congestion and cerebral edema in hypertensive patients [15].

It should be noted that reports of arterial flow dynamics in patients with progressing $\mathrm{WMH}$ are controversial: some authors reveal a decline in the arterial flow rate [16], whereas others point to the lack of association between leukoaraiosis and impaired cerebral circulation [14]. Research into the association between $\mathrm{WMH}$ and cerebral circulation [17] demonstrated that patients with initially more severe $\mathrm{WMH}$ developed serious impairments of cerebral blood flow and not the other way around: impaired cerebral circulation did not precede the progression of $\mathrm{WMH}$. It was concluded that a reduction in the brain tissue volume causes a decline in the cerebral blood flow rate. The association between increased arterial flow and Fazekas 1 established by our study and the lack of significant differences in blood flow rates between patients with Fazekas 2 and the controls confirm the role of non-ischemic mechanisms in the development of early $\mathrm{WMH}$ and a possible reduction in blood flow in response to brain matter damage in patients with pronounced $\mathrm{WMH}$ [3].

Our study demonstrates that a gradual reduction in blood flow leads to an increase in the number of lacunes. These findings are consistent with the results of other studies [18] and confirm that ischemia does play a role in the formation of lacunar cavities. Our study also reveals a correlation between reduced blood flow in the upper sagittal and straight sinuses, as well as increased CSF flow and the elevated intracranial compliance index, and the formation of multiple lacunes, which possibly reflects the severity of brain damage in patients with multiple lacunes [19].

Importantly, we observed an association between the elevated pulsatility index and an increase in the number of lacunar cavities, as well as in WHM severity, which is again consistent with other research works [18]; another association between the increased pulsatility index and the dilation of PVS was not discussed in the literature previously. Elevated $\mathrm{Pi}$ is a sign of reduced elasticity of arterial walls associated with their high permeability and swelling that eventually lead to arteriolosclerosis in hypertensive and non-hypertensive patients with SVD [20]. Increased pulsatile pressure cannot be attenuated by the windkessel mechanism; therefore, more pulsation is "absorbed" by veins [21]. This obstructs drainage of the interstitial fluid from PVS and promotes accumulation of toxic waste products, leading to PVS dilation and WMH [22]. The latter has been actively discussed in the literature in the context of a recently described glymphatic system (a waste clearance system of the brain) [23] and could explain the associations between $\mathrm{Pi}$ and PVS size; also, it is possibly another contributor to $\mathrm{WMH}$. At present, there is ongoing debate in the literature over the associations between the cerebral venous collagenosis and venous ischemia, increased vascular resistance, disrupted interstitial fluid circulation and damage to BBB accompanied by a vasogenic edema, which, in turn, provides another explanation for WMH [22]. It is still not known whether damage to the venules is caused by a pressure surge or develops independently. Interestingly, $\mathrm{WMH}$ (leukoaraiosis) are commonly found in the regions where deep veins perform their drainage function and are less pronounced in the regions 
A

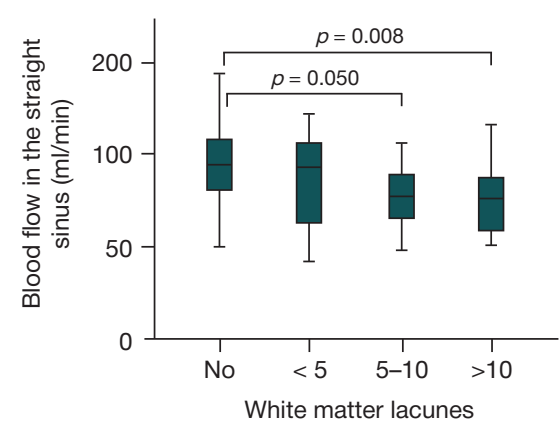

D

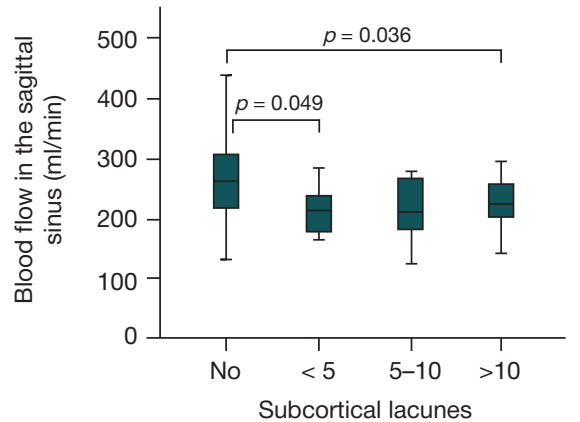

B

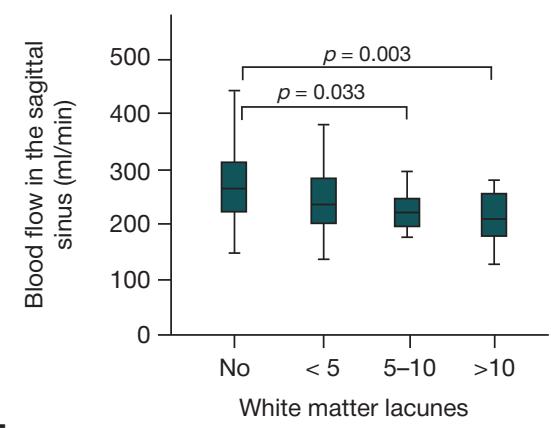

E

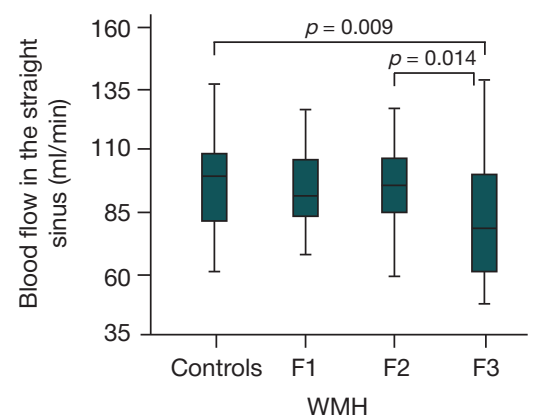

C

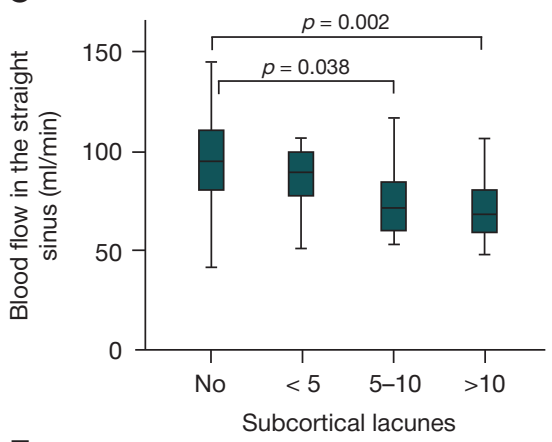

$\mathbf{F}$

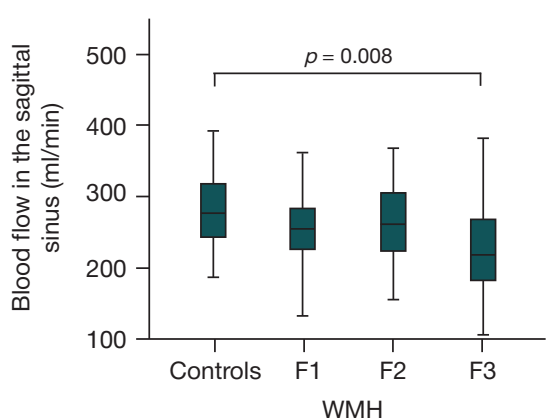

Fig. 4. Comparison of venous blood flow parameters between the controls and the patients with lacunes (A-D) and WMH assessed using the Fazekas scale (E-F)

A

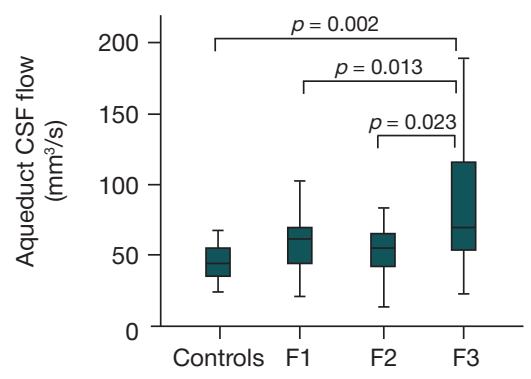

B

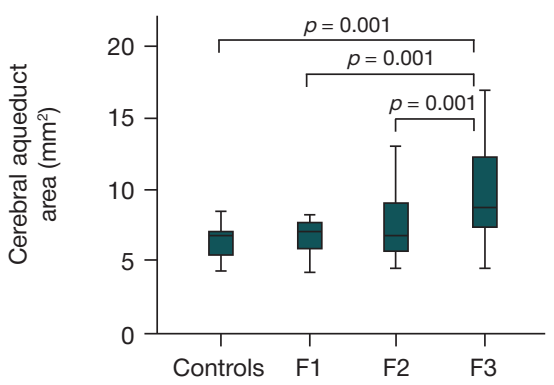

C

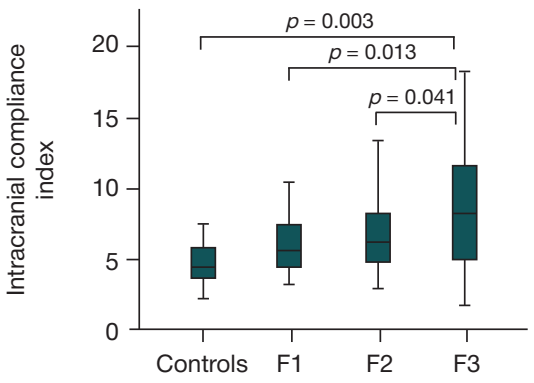

D

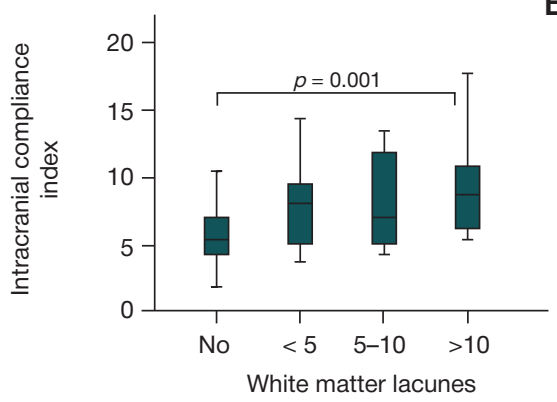

E

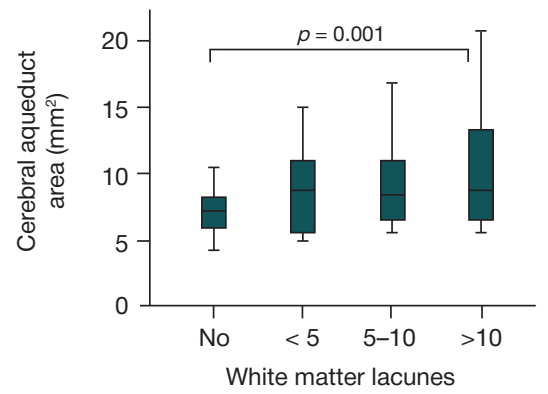

Fig. 5. Comparison of CSF flow parameters and the intracranial compliance index between the controls and the patients with WMH measured on the Fazekas scale $(\mathrm{A}-\mathrm{C})$ and lacunes $(\mathrm{D}-\mathrm{E})$

of superficial veins. However, we found statistically significant associations between reduced venous flow in the upper and straight sagittal sinuses and early $(<5)$ microbleeds, which confirms the important role of cortical veins in maintaining intracranial compliance [24] and the link between their damage or rupture and broken autoregulation mechanism.

In our opinion, microbleeds and their association with blood or CSF flow impairments should be discussed at length. Single and multiple MB were observed in more than one-third of patients. The majority of the lesions were localized to either subcortical or juxtacortical structures; both localizations were observed in $56.8 \%$ of patients [25]. Some authors point to an association between $\mathrm{MB}$ localizations and the nature of the pathology: MB found in the subcortical ganglia are associated with hypertension, whereas those localized to juxtacortical or cortical structures, with cerebral amyloid angiopathy [26]. Because patients from our sample did not have lobar and superficial MB, which signal cerebral amyloid angiopathy (CAA) and are used as a criterion for its diagnosis in vivo, we cannot rule out early CAA in some of the participants, given the upper age limit applied in our study. At the same time, MB were the most pronounced in the Fazekas 3 group characterized by multiple lacunes that are not typical of CAA [27]. A recent comparison of data yielded by MRI and Pittsburg compound 
PET showed that the presence of $\mathrm{MB} /$ hemorrhages in both subcortical and juxtacortical structures were more typical for hypertensive patients with SVD than for those with CAA [28]. Our previous findings showed a correlation between juxtacortical/ deep $\mathrm{MB}$ and the volume of superficial veins and another correlation between deep/periventricular $\mathrm{MB}$ and the volume of deep veins [29], so we drew a conclusion about a possible role of venous congestion in the corresponding regions in the formation of variously localized MB, similarly to how it occurs in cerebral venous sinus thrombosis. The proposed mechanism could explain the cooccurrence of $\mathrm{MB}$ in subcortical structures and the subcortical white matter. Prospective observation of these patients will help us to investigate the prognostic value of MB localization and its combination with other MRI features as markers of early SVD. This is particularly important, because the overuse of antiplatelets is one of the leading factors for lobar hemorrhage in elderly patients.

\section{References}

1. Dumoulin CL, Yucel EK, Vock P, et al. Two- and three-dimensional phase contrast MR angiography of the abdomen. J Comput Assist Tomogr. 1990; (14): 779-84.

2. Halperin JJ, Kurlan R, Schwalb JM, Cusimano MD, Gronseth G, Gloss D. Practice guideline. Idiopathic normal pressure hydrocephalus: Response to shunting and predictors of response. Report of the Guideline Development, Dissemination, and Implementation Subcommittee of the American Academy of Neurology. Neurology. 2015; (85): 2063-71.

3. Ahmetzyanov BM, Kremneva El, Morozova SN, Dobrynina LA Krotenkova MV. Vozmozhnosti magnitno-rezonansnoj tomografii $v$ ocenke likvornoj sistemy $v$ norme i pri razlichnyh zabolevanijah nervnoj sistemy. Russian electronic journal of radiology. 2018; 8 (1): 145-66. Russian.

4. Pantoni L. Cerebral small vessel disease: from pathogenesis and clinical characteristics to therapeutic challenges. Lancet Neurol. 2010; (9): 689-701.

5. Shahparonova NV, Kadykov AS. Hronicheskie sosudistye zabolevanija golovnogo mozga: algoritm diagnostiki i lechenija. Consilium Medicum. 2017; 19 (2): 104-9.

6. Wardlaw JM, Smith C, Dichgans M. Mechanisms of sporadic cerebral small vessel disease: insights from neuroimaging. Lancet Neurol. 2013; (12): 483-97.

7. Rost NS, Rahman RM, Biffi A, et al. White matter hyperintensity volume is increased in small vessel stroke subtypes. Neurology. 2010; (75): 1670-7.

8. Gulevskaya TS. Patologija belogo veshhestva polusharij golovnogo mozga pri arterial'noj gipertonii s narushenijami mozgovogo krovoobrashhenija [dissertacija]. M., 1994.

9. Wardlaw JM, Smith EE, Biessels GJ, et al. Neuroimaging standards for research into small vessel disease and its contribution to ageing and neurodegeneration. Lancet Neurol. 2013; (12): 822-38.

10. Kim KW, MacFall JR, Payne ME. Classification of white matter lesions on magnetic resonance imaging in elderly persons. Biol Psychiatry. 2008; (64): 273-80.

11. Harper L, Barkhof F, Fox NC, Schott JM. Using visual rating to diagnose dementia: a critical evaluation of MRI atrophy scales. J Neurol Neurosurg Psychiatry. 2015; 86 (11): 1225-33. DOI: 10.1136/jnnp-2014-310090.

12. Fazekas F, Chawluk JB, Alavi A, et al. MR signal abnormalities at $1.5 \mathrm{~T}$ in Alzheimer's dementia and normal aging. AJR Am J Roentgenol. 1987; 149 (2): 351-6.

13. Pantoni L, Basile AM, Pracucci G, Asplund K, Bogousslavsky J, Chabriat $\mathrm{H}$. et al. Impact of age-related cerebral white matter changes on the transition to disability: the LADIS study: rationale, design and methodology. Neuroepidemiology. 2005; 24: 51-62.

14. Henry-Feugeas MC, Roy C, Baron G, Schouman-Claeys E. Leukoaraiosis and pulse-wave encephalopathy: observations with

\section{CONCLUSIONS}

The established associations between MRI findings and arterial, venous and CSF flow impairments in patients with SVD suggest the important role of mechanisms implicated in the disruption of Monro-Kellie intracranial homeostasis in promoting SVD. Most likely, the initial contribution is done by increased arterial pulsatility, as suggested by the universal association between this parameter and other clinical manifestations (cognitive decline and gait disturbances), as well as diagnostic features of SVD visible on MRI. This determines the clinical relevance of interpreting the acquired MR images using STRIVE advisory standards and analyzing the hemodynamic parameters of blood and CSF flow based on PC-MRI data in patients with SVD in order to assess the efficacy of the applied treatment or prevention measures.

phase contrast MRI in mild cognitive impairment. J Neuroradiol. 2009; (36): 212-8.

15. Schmidt R, Schmidt H, Haybaeck J, et al. Heterogeneity in agerelated white matter changes. Acta Neuropathol. 2011; (122): 171-85.

16. Shi Y, Wardlaw J. Update on cerebral small vessel disease: a dynamic whole-brain disease. Stroke and Vascular Neurology. 2016; (2): 83-92.

17. Van der Veen $\mathrm{PH}$, Muller $\mathrm{M}$, Vincken $\mathrm{KL}$, et al. Longitudinal relationship between cerebral small-vessel disease and cerebral blood flow: the second manifestations of arterial disease-magnetic resonance study. Stroke. 2015; (46): 1233-8.

18. Poels MM, Zaccai K, Verwoert GC, et al Arterial stiffness and cerebral small vessel disease: the Rotterdam Scan Study. Stroke. 2012; (43): 2637-42

19. Kremneva El, Akhmetzyanov BM, Gadzhieva ZSh, Sergeeva AN, Zabitova MR, Morozova SN, et al. Assessment of different pathogenetic mechanisms and disease progression in sporadic cerebral small vessel disease patients based on MRI STRIVE criteria. Neuroradiology. 2018; 60 (suppl 2): S430-S430.

20. Shi Y, Thrippleton MJ, Marshall I, Wardlaw JM. Intracrania pulsatility in patients with cerebral small vessel disease: a systematic review. Clinical Science (London). 2018; 32 (1): 157-71.

21. Bateman GA, Levi CR, Schofield P, et al. The venous manifestations of pulse wave encephalopathy: windkessel dysfunction in normal aging and senile dementia. Neuroradiology. 2008; (50): 491-7.

22. Potter GM, Doubal N, Jackson CA, et al. Enlarged perivascular spaces and cerebral small vessel disease. Int J Stroke. 2015; (10): 376-81.

23. Mestre H, Kostrikov S, Mehta RI, Nedergaard M. Perivascular spaces, glymphatic dysfunction, and small vessel disease. Clinical science. 2017; (131): 2257-74.

24. Vignes JR, Dagain A, Guerin J, Liguoro D. A hypothesis of cerebral venous system regulation based on a study of the junction between the cortical bridging veins and the superior sagittal sinus. Laboratory investigation. J Neurosurg. 2007; (107): 1205-10.

25. Zabitova MR, Shabalina AA, Dobrynina LA, Kostyreva MV, Ahmetzyanov BM, Gadzhieva ZSh, i dr. Tkanevoj aktivator plazminogena i MRT-priznaki cerebral'noj mikroangiopatii. Annaly klinicheskoj i jeksperimental'noj nevrologii. 2018; 12 (4): 30-6.

26. Charidimou A, Pantoni L, Love S. The concept of sporadic cerebral small vessel disease: A road map on key definitions and current concepts. Int J Stroke. 2016; 11 (1): 6-18.

27. Greenberg SM, Vernooij MW, Cordonnier C. Cerebral microbleeds: a guide to detection and interpretation. Lancet Neurol. 2009; (8): 165-74.

28. Tsai $H H$, Pasi $M$, Tsai $L K$, et al. Microangiopathy underlying mixed-location intracerebral hemorrhages / microbleeds: A PiB- 
PET study. Neurology. 2019; 92 (8): e774-e781. DOI: 10.1212/ WNL.0000000000006953.

29. Ahmetzyanov BM. Rol' narushenij krovotoka i likvorotoka $v$ porazhenii golovnogo mozga pri cerebral'noj mikroangiopatii [dissertacija]. M., 2019.

\section{Литература}

1. Dumoulin CL, Yucel EK, Vock P, et al. Two- and three-dimensional phase contrast MR angiography of the abdomen. J Comput Assist Tomogr. 1990; (14): 779-84.

2. Halperin JJ, Kurlan R, Schwalb JM, Cusimano MD, Gronseth G, Gloss D. Practice guideline. Idiopathic normal pressure hydrocephalus: Response to shunting and predictors of response. Report of the Guideline Development, Dissemination, and Implementation Subcommittee of the American Academy of Neurology. Neurology. 2015; (85): 2063-71.

3. Ахметзянов Б. М., Кремнева Е. И., Морозова С. Н., Добрынина Л. А., Кротенкова М. В. Возможности магнитнорезонансной томографии в оценке ликворной системы в норме и при различных заболеваниях нервной системы. Russian electronic journal of radiology. 2018; 8 (1): 145-66.

4. Pantoni L. Cerebral small vessel disease: from pathogenesis and clinical characteristics to therapeutic challenges. Lancet Neurol. 2010; (9): 689-701.

5. Шахпаронова Н. В., Кадыков А. С. Хронические сосудистые заболевания головного мозга: алгоритм диагностики и лечения. Consilium Medicum. 2017; 19 (2): 104-9.

6. Wardlaw JM, Smith C, Dichgans M. Mechanisms of sporadic cerebral small vessel disease: insights from neuroimaging. Lancet Neurol. 2013; (12): 483-97.

7. Rost NS, Rahman RM, Biffi A, et al. White matter hyperintensity volume is increased in small vessel stroke subtypes. Neurology. 2010; (75): 1670-7.

8. Гулевская Т. С. Патология белого вещества полушарий головного мозга при артериальной гипертонии с нарушениями мозгового кровообращения [диссертация]. М., 1994.

9. Wardlaw JM, Smith EE, Biessels GJ, et al. Neuroimaging standards for research into small vessel disease and its contribution to ageing and neurodegeneration. Lancet Neurol. 2013; (12): 822-38.

10. Kim KW, MacFall JR, Payne ME. Classification of white matter lesions on magnetic resonance imaging in elderly persons. Biol Psychiatry. 2008; (64): 273-80.

11. Harper L, Barkhof F, Fox NC, Schott JM. Using visual rating to diagnose dementia: a critical evaluation of MRI atrophy scales. J Neurol Neurosurg Psychiatry. 2015; 86 (11): 1225-33. DOI: 10.1136/jnnp-2014-310090.

12. Fazekas F, Chawluk JB, Alavi A, et al. MR signal abnormalities at $1.5 \mathrm{~T}$ in Alzheimer's dementia and normal aging. AJR Am J Roentgenol. 1987; 149 (2): 351-6.

13. Pantoni L, Basile AM, Pracucci G, Asplund K, Bogousslavsky J, Chabriat $\mathrm{H}$. et al. Impact of age-related cerebral white matter changes on the transition to disability: the LADIS study: rationale, design and methodology. Neuroepidemiology. 2005; 24: 51-62.

14. Henry-Feugeas MC, Roy C, Baron G, Schouman-Claeys E. Leukoaraiosis and pulse-wave encephalopathy: observations with phase contrast MRI in mild cognitive impairment. J Neuroradiol. 2009; (36): 212-8.

15. Schmidt R, Schmidt H, Haybaeck J, et al. Heterogeneity in age-

related white matter changes. Acta Neuropathol. 2011; (122): 171-85.

16. Shi Y, Wardlaw J. Update on cerebral small vessel disease: a dynamic whole-brain disease. Stroke and Vascular Neurology. 2016; (2): 83-92.

17. Van der Veen PH, Muller M, Vincken $\mathrm{KL}$, et al. Longitudinal relationship between cerebral small-vessel disease and cerebral blood flow: the second manifestations of arterial disease-magnetic resonance study. Stroke. 2015; (46): 1233-8.

18. Poels MM, Zaccai K, Verwoert GC, et al Arterial stiffness and cerebral small vessel disease: the Rotterdam Scan Study. Stroke. 2012; (43): 2637-42.

19. Kremneva El, Akhmetzyanov BM, Gadzhieva ZSh, Sergeeva AN, Zabitova MR, Morozova SN, et al. Assessment of different pathogenetic mechanisms and disease progression in sporadic cerebral small vessel disease patients based on MRI STRIVE criteria. Neuroradiology. 2018; 60 (suppl 2): S430-S430.

20. Shi Y, Thrippleton MJ, Marshall I, Wardlaw JM. Intracranial pulsatility in patients with cerebral small vessel disease: a systematic review. Clinical Science (London). 2018; 32 (1): 157-71.

21. Bateman GA, Levi CR, Schofield $P$, et al. The venous manifestations of pulse wave encephalopathy: windkessel dysfunction in normal aging and senile dementia. Neuroradiology. 2008; (50): 491-7.

22. Potter GM, Doubal N, Jackson CA, et al. Enlarged perivascular spaces and cerebral small vessel disease. Int J Stroke. 2015; (10): 376-81.

23. Mestre H, Kostrikov S, Mehta RI, Nedergaard M. Perivascular spaces, glymphatic dysfunction, and small vessel disease. Clinical science. 2017; (131): 2257-74

24. Vignes JR, Dagain A, Guerin J, Liguoro D. A hypothesis of cerebral venous system regulation based on a study of the junction between the cortical bridging veins and the superior sagittal sinus. Laboratory investigation. J Neurosurg. 2007; (107): 1205-10.

25. Забитова М. Р., Шабалина А. А., Добрынина Л. А., Костырева М. В., Ахметзянов Б. М., Гаджиева З. Ш. и др. Тканевой активатор плазминогена и МРТ-признаки церебральной микроангиопатии. Анналы клинической и экспериментальной неврологии. 2018; 12 (4): 30-6.

26. Charidimou A, Pantoni L, Love S. The concept of sporadic cerebral small vessel disease: A road map on key definitions and current concepts. Int J Stroke. 2016; 11 (1): 6-18.

27. Greenberg SM, Vernooij MW, Cordonnier C. Cerebral microbleeds: a guide to detection and interpretation. Lancet Neurol. 2009; (8): 165-74.

28. Tsai $H H$, Pasi $M$, Tsai $L K$, et al. Microangiopathy underlying mixed-location intracerebral hemorrhages / microbleeds: A PiBPET study. Neurology. 2019; 92 (8): e774-e781. DOI: 10.1212/ WNL.0000000000006953.

29. Ахметзянов Б. М. Роль нарушений кровотока и ликворотока В поражении головного мозга при церебральной микроангиопатии [диссертация]. М., 2019. 